\title{
The development of reading comprehension learning material by SQ4R strategy for grade iv at primary schools
}

\author{
Meiliza Sari ${ }^{1}$, Sufyarma Marsidin ${ }^{2}$, dan Darnis Arief ${ }^{3}$ \\ ${ }^{123}$ Universitas Negeri Padang, Padang - Indonesia, ( meiliza200594@gmail.com)
}

\begin{abstract}
Teachers have responsibility to create and develop an effective learning material in order to facilitate the student to understand the reading content optimally. There are, it is important to develop an effective learning material by using SQ4R strategy as the solution The type of this research is R\&D by using 4 -D model. The sample were 42 students and 2 teachers in primary school. The result of the research indicated that the validity rate of the learning material is valid. Then upon the assessment on the implementation of lesson plan, the responses from teachers and learning participants and the observations on teaching materials indicated that the practicality rate fell to the category of highly practical. Moreover, the result of the activity of learning participants on reading comprehension indicated to be effective. Hence, it could be concluded that the developed reading comprehension learning material by using SQ4R strategy has already been valid, practical, and effective.
\end{abstract}

Keywords: learning material, reading comprehension, SQ4R strategy, 4-D models.

This is an open access article distributed under the Creative Commons 4.0 Attribution License, which permits unrestricted use distribution, and reproduction in any medium, provided the original work is properly cited. @2018 by author and Faculty of education, UniversitasNegeri Padang.

\section{Introduction}

Learning which is followed by teaching materials on every subject is one of the important factors that can encourage the learning activities includingBahasa Indonesia subject.

Bahasa Indonesia subject contains four aspects of skills such as listening, speaking, reading, and writing. There were so many reserach that had been done about reading skills such as the research in Turkey ( by ErdalPapatga and Ali Ersoy, 2016), America (by HacerUlu and HayatiAkyol, 2016), Singapore (by Wilkinson Daniel and Patrisha Lliane, 2016), Los Angeles (by Samuel Smith, 2016), Colombia (by Amy Barth, Sharon Vaugh, and Elisabeth Mclluey, 2015), Japan (by Jonathan Aliponga, 2013), and in Indonesia ( by Junaidi Mistar, AlfanZuhairi, and Novita Yanti).

Generally, the results of research showedthe big impact of reading in the successful in learning of the students. More they understand towards reading so it will give them a positive impact, their knowledge will get increased.

Several studies talked about the problem of reading skills, such as a research in Europe (by Santos Lazzeri, XimenaCabezas, and Luis Ojeda, 2015), Saudi Arabia (by Joel Meniado, 2015), Australia (by Evan Ortlieb, 2013), America (by Hugh Catts and AlnKamhi, 2017), Turkey (by Kasim Yuldirim and SayitAtes, 2012), and in the United States (by Marcedes Spencer, Jamie Quinn, and Richard Wagner, 2014) 
The results of the study revealed that some problems that always appear in reading among readers were : (1) a low reading skill in comprehending by learners, ( 2 The teachers only used one source or an available textbook at school, (3) a motivation of the students in reading is poor, (4)the difficulty of the students in deciding the meaning of reading, (5) the information of the text was difficult to find by the learners, (6) teachers did not direct learners on predicting activities before reading, and (7) the teacher did not guide the students in determining the conclusions, thus it affectedtowards the difficulties of students in responding to questions related to the text.

Besides, based on the results of backround of the study that the writer have done at SDN 18 Air Tawar Selatan, Padang Utara on March,18th 2017 which was done in less than two weeks, found some problems in learning process, especially on reading comprehension skills and teaching materials used by the teachers.

These problems can be described as follows, (1) teaching materials used by teachers did not contain complete reading stages, (2) the students were directly asked to answer the questions contained in teaching materials without passing the reading stage as they should do, (3) reading learning indicators could not go properly (4) there was no variation in the color and image of teaching materials, (5) the students were not interested to the text (6) the teacher used only one textbook provided in the School, (7) teachers did not lead them in the reading stagse so they became difficult in making predictions, understand the contents of the text, find the main idea, principal thoughts, and in making conclusions from the texts. Reading problems raised above will lead to the lack of the ability of the students to summarize and understand the readings.

Teaching materials that teachers use in learning process do not attract the attention of students, with a monotonous design and lack of color variations and images in order to attract them to read with the spirit of learning, so it is far away from the characteristics of elementary students who like something new, colored, and varied.

An example of a strategy that teachers can apply in using teaching materials for the students is the SQ3R strategy that has been developed into SQ4R (Survey, Question, Read, Recite Rite, and Review). Teaching materials that is appropriate to the students' need and the use of SQ4R (Survey, Question, Read, Recite Rite, and Review) gives a very positive impact on the successful of learning Indonesian language, one of which is in reading activity.

Several studies have been conducted about SQ4R strategies that are proven can improve and make it easier for the students and the teachers in learning process. SQ4R strategy also provides high motivation for students to read and make students enjoy in reading. Such as a research in Iran (by NaghesShahri, ShahramVaziri and FarhLotfi, 2015), Indonesia (by Fatima Dewi, Pure Sapta, Dan Susilowati, 2017), Turkey (by Murat Basar and Mehmet Gurbuz, 2017), and Amsterdam (by MarloesMuijselaar and Nicole Swart, 2017).

The results of the study showed that reading skills of the students using the SQ4R strategy gave a big influence. Students looked happy in learning process and more easily understand in reading following each step of the SQ4R strategy, in addition the teacher will be easier and more focused in doing learning process, and they can master every activities that has been directed in using the strategy SQ4R.

\section{Method}

The development model used in this study is 4-D model, Menurut Sugiyono (2008: 404) stages of 4-D model, among others:define, design, development, and disseminate Description of research data is described as follows:

1. Definition Stage (Define); At this stage of analyzing, conducted an analysis consisting of 3 aspects that include: curriculum analysis, needs analysis, and analysis of learners. 
2. Stage Design (Design); The design stage is to design reading comprehension materials using SQ4R strategy in grade IV SD. Teaching materials adapted to SK and KD is set by curriculum, Development of teaching materials agrees to the characteristics of the development of the students. The teaching materials which is colorful can make them interest. Thus, teaching materials will be enjoyed by them and can support the learning process.

3. Development Stage (Develop); This development phase aims to produce reading comprehension materials using SQ4R strategy that is valid, practical and effective, so it is worthy to be used in the learning process. This stage consists of three stages: design validation, practicality test, and effectiveness test.

4. Disseminate Stage; In this stage talks about the use of teaching materials on a wider scope. This spread can be done in other classes, other schools, or other teachers. In this study, the distribution was done at another school, SDN 25 Air Tawar Selatan. The goal is to test the effectiveness of the use of these devices on different objects, situations, and conditions.

\section{Results and Discussion}

The development of reading comprehension materials using the SQ4R strategy by adopting the 4$D$ development model has been successfully implemented. The teaching materials have been tested in class IV SDN 18 Air Tawar Selatan with 25 students and conducted the dissemination in another school that is SDN 25 Air Tawar Selatan in class IV with 17 people.

\section{Validity of Learning Materials Reading Comprehension Using the SQ4R Strategy}

Teaching materials developed in this study consider the component of teaching materials. Hamdani (2011: 122) explained that to compose teaching materials should consider some components contained in a teaching materials, including: (a) title, subject, competency standard, basic competence, indicators, and learning objectives, (b) instructional (instructions of learners and teachers) contains explanations on how to use a teaching material to be learned in a learning process, (c) supporting information, (d) exercises, at the end of the chapter, end of chapter, end of semester, and ( e) evaluation. Validation in this research was done by 3 expert validator and 3 validator of practitioner.

\section{Practicality of Learning Materials Reading Comprehension Using the SQ4R Strategy}

Seeing whether the learning materials that were developed practically or not, were tested on the students of class V SDN 18 Air Tawar Selatan Kota Padang. Looking at the RPP that has been developed before, then the learning process is done once a meeting with a time allocation of $4 \times 35$ minutes. The observed practices were the level of implementation of the RPP, the teachers' response questionnaire, the students' response questionnaire, and the interview on the practicalities of learning tools.

\section{The Effectiveness of Learning Materials Reading Comprehension Using the SQ4R Strategy}

The effectiveness test was done to see the aspect of activity, process assessment, and assessment of the writing result of the students. The first was seen from aspects of learning activities of learners. Activity in learning has a very important role in the learning process. Therefore, the activity needs to be seen learning activities of learners using teaching materials. According Sardiman (2008: 100) there are 7 activities in learning. However, in this study, researchers only used 5 learning activities that were blessed with the use of narrative writing materials such as visual activities, listening activities, oral activities, writing activities, and motor activities.

Results of this research on the development of learning materials to read the understanding using the model SQ4R in grade IV SD. Overall the results of the study was based on validity, practicality and effectiveness can be seen in the table below: 
Tabel 1. Recapitulation Of Learning Materias Assesment

\begin{tabular}{cllcc}
\hline No. & & Aspect & Result & Category \\
\hline $\mathbf{1}$ & Validity & Content & $94,2 \%$ & Very valid \\
& & Language & $90 \%$ & Very valid \\
& & Graffiti & $93,7 \%$ & Very valid \\
\multirow{2}{*}{} & \multirow{2}{*}{ Practicalty } & RPP implementation & $93,05 \%$ & Very simple \\
& & Teachers response & $97,5 \%$ & Very simple \\
& & Student response & $90,9 \%$ & Very simple \\
\multirow{2}{*}{ Effectiveness } & & Student activities & $91,6 \%$ & Very high \\
& & Student reading process & $87,10 \%$ & Very high \\
& & Student reading result & $96 \%$ & Very high \\
\hline
\end{tabular}

\section{Conclusion}

The results of the validity of the study indicated that learning materials to read the understanding using SQ4R strategy in grade IV Primary School in this study was valid from content and constructs side. This is in suitable with validation results from expert validator and validator of education practitioner. These results illustrated that the teaching material developed has been valid and can be used in the learning process.

The result of practicability showed that the reading comprehension materials using the SQ4R strategy in grade IV of the Elementary School as a whole is very efficient. This is obtained from the observation of the implementation of RPP on teachers who teach, teacher's response, student's response, and the use of teaching materials. This result provided an illustration that the teaching materials are very effecient and can assist in implementing the learning process of reading comprehension in grade IV of elementary school.

The Effectiveness results showed that learning materials reading comprehension using SQ4R strategy in grade IV of elementary school can be known through the students' activity, process assessment, and assessment of reading comprehension result learners. The observation of learners 'activity, process assessment, and assessment of reading result of students' understanding gave a very good picture, meaning that the use of teaching materials in reading learning has been effectively implemented.

\section{Reference}

Abbas, S. (2006). Pembelajaran Bahasa Indonesia yang Efektif di Sekolah Dasar. Jakarta: Depdiknas Abidin, Y. (2012). Pembelajaran Bahasa Berbasis Pendidikan Karakter. Bandung: Refika Aditama

Alaa, B, K. (2016). The Impact of Using Jigsaw Strategy on Improving Reading Comprehension and Communication Skillsamong Eleventh Graders in Rafah. Eric Doc.

Barth, A. E, S., \& Mcculley, E, V. (2015). The effects of blended text-processing and linguistic comprehension interventions among struggling middle-school readers. International Journal for Research in Learning Disabilities, 2(2), 2-17.

Basar, M. (2017).Effect of the SQ4R Technique on the Reading Comprehension ofElementary School 4th Grade Elementary School Student. Eric Doc

Erdal, P, \& Ali, E. (2016). Improving Reading Comprehension Skills Throughthe SCRATCH Program International Electronic Journal of Elementary Education, 9(1), 124-150. 
İbrahim, Y \& Selcuk B, D. (2017). Examination of the Relation between TEOG Score of Turkish Revolution History and Kemalism Course and Reading Comprehension Skill (An Example of Explanatory Sequential Mixed Design). Journal of Education and Practice. 34 (7).

Gulhiz, P. (2016). The Evaluation of Effectiveness of Reciprocal Teaching Strategies on Comprehension of Expository Texts. Journal of Education and Training Studies, 4 (10).

Hamdani. (2011). Strategi Belajar Mengajar. Bandung: Pustaka Setia.

Hacer, U \& Hayati, A. (2016). The Effects of Repetitive Reading and PQRS Strategyinthe Development of Reading Skill. Eurasian Journal of Educational Research, 63, 225-242

Hairul, N, I, Mohammad, R, A \& Abbas, P, G. (2012). The role of SQ4R strategy as an important factor of improving reading motivation. Malaysian Journal of Education Technology, Eric Doc.

Hugh W, C \& Alan G, K. (2017). Reading Comprehension Is Not a Single Ability. Eric Doc.

Jonathan, A. (2013). Reading Journal: Its Benefits for Extensive Reading. International Journal of Humanities and Social Science, 12 (3). 1-8.

Joel, C, M. (206). Metacognitive Reading Strategies, Motivation, and Reading Comprehension Performance of Saudi EFL Students. Journal Eanglish Language. 9 (3).

Joseph L, M, Sheila A, M, Jennifer C, \& Christina R. (2015). The Effects of Self Questioning on Reading Comprehension: A Literature Review. Eric Doc

Kemendiknas. (2010). Petunjuk Teknis Pengembangan Bahan Ajar SMA. Jakarta: Kemendiknas, Direktorat Jenderal Manajemen Pendidikan Dasar dan Menengah

Mercedes, S, Jamie, M, Q, \& Richard, K, W. (2014). Specific Reading Comprehension Disability: Major Problem, Myth, or Misnomer?. Journal of Learning Disabilities Research \& Practice, 29(1), 3-9

Mustafa, K. (2016). An exploratory study of the relationships betweenreading comprehension competence, readingattitude and the vividness of mental imagery amongTurkish fourth-grade students. International Electronic Journal of Elementary Education, 8(4), 675-686.

Narges, S, S, V, \& Farh L, K. (2015). Effectiveness of Cognitive and Metacognitive Strategies and SQ4R Methods in Reducing Test Anxiety In Students. International Journal of Fudamental Psychology and Social Science. 5 (4). 41-45

Nurul, L, K . \& Ninuk L. (2017).Improving English Reading Comprehension Ability through Survey, Questions, Read, Record, Recite, Review Strategy (SQ4R). Journal Eanglish Language Teaching. 10 (12). 1-10

Rahim, F. (2012). Pengajaran Membaca di Sekolah Dasa.

Seher, B. (2017). Reading Comprehension Skills OfBilingual Children In Turkey. European Journal of Education Studies. 3 (6).

Santos, L, Ximena, C, Luis, O, \& Francisca, L. (2015). Automated formative evaluations for readingcomprehension in an English as a foreign languagecourse: benefits on performance, user satisfaction, and monitoring of higher education students in Chile. Eric Doc.

Samuel, S. (2010). Is There A Correlation Between The Use Of Accelerated Reader In The Classroom And Student Achievement In Reading Comprehension?. Eric Doc.

Shahri, N. 2015. Effectiveness of Cognitive and Metacognitive Strategies and SQ4R Methods in Reducing Test Anxiety In Student. Eric Doc 